\title{
WYKORZYSTANIE METOD PRZYROSTOWYCH W BUDOWIE I OBRÓBCE ELEMENTÓW KOMPOZYTOWYCH O ZLOŻONEJ GEOMETRII
}

\begin{abstract}
W niniejszej pracy przedstawiono problematykę wykorzystania metod przyrostowych w budowie i obróbce elementów kompozytowych o złożonej geometrii, jako składową szerszego projektu poświęconego budowie zespołu chłodzącego ogniwo paliwowe motoszybowca AOS-H2. Zważywszy na niewielkie wymiary części kompozytowych (jak na warunki zastosowań danego materiału), konieczne było wprowadzenie druku 3D, jako technologii pomocniczej zarówno w trakcie laminowania, obróbki półfabrykatów, jak również jako tańszą i szybszą alternatywę produkcyjną stempli dociskowych. Zastosowanie metod przyrostowych wpłynęło nie tylko na poprawę jakości gotowego wyrobu, ale również było niezbędne, aby niektóre z elementów wentylatora, wbrew powszechnej opinii, mogły zostać wykonane z włókna węglowego w tak niewielkiej skali (np. łopatki, których wysokość nie przekraczała $50 \mathrm{~mm}$ ). Wprowadzenie druku 3D do pracy z laminatem umożliwiło użycie kompozytu do budowy elementów o złożonej geometrii i stosunkowo niewielkich wymiarach.
\end{abstract}

Słowa kluczowe: kompozyt, włókno węglowe, druk 3D, metody przyrostowe

\section{Wprowadzenie}

Współczesna inżynieria lotnicza skupia się na zwiększaniu efektywności i szeroko rozumianej sprawności maszyn latających, prowadzących do zmniejszenia kosztów eksploatacyjnych [1]. W dalszym ciągu to masa i niezawodność podzespołów wchodzących $\mathrm{w}$ skład samolotu są czynnikami determinującymi i wpływającymi w sposób decydujący na to, czy jest on akceptowalny ze względów ekonomicznych i coraz to istotniejszych względów ekologicznych [2]. Pomijając kwestie napędu i jego spalanie, to właśnie materiały kompozytowe (kompozyty polimerowe) wydają się być najtrafniejszą drogą dla nowoczesnego lotnictwa [3], sprawiającą, że sprosta ono wymaganiom światowego rynku. Zwiększanie składu procentowego części kompozytowych w strukturze płatowca

\footnotetext{
${ }^{1}$ Autor do korespondencji: Katarzyna Kaczorowska, Politechnika Rzeszowska im. Ignacego Łukasiewicza, al. Powstańców Warszawy 12, 35-959 Rzeszów, e-mail: kaczorowskakatarzyna15@ gmail.com, ORCID: 0000-0002-9704-4119.

2 Michał Jakubowski, Politechnika Rzeszowska im. Ignacego Łukasiewicza, al. Powstańców Warszawy 12, 35-959 Rzeszów.
} 
[4] jest obecnie dosyć popularne, natomiast sprawa ma się zupełnie odwrotnie, jeśli chodzi o części mechaniczne, mówiąc precyzyjniej podzespoły samolotu często o niewielkich wymiarach, ale silnie obciążone złożonym stanem naprężeń. Sposoby projektowania i wykonywania takich elementów przy użyciu technologii kompozytowej albo nie są jeszcze ogólnodostępne, albo w ogóle nie zostały jeszcze opracowane [5]. Autorzy niniejszego artykułu zostali postawieni przed zadaniem zaprojektowania, opracowania technologii produkcji i wykonania kompozytowej, dwustopniowej turbiny chłodzącej ogniowo paliwowe motoszybowca AOS-H2 [6] o maksymalnych wymiarach średnicowych nieprzekraczających $200 \mathrm{~mm}$ przy zadanym napędzie wentylatorów generujących przepływ powietrza w postaci silników elektrycznych Hacker Q80-13XS, ograniczających długość łopatek ze względów konstrukcyjnych do jedynie $50 \mathrm{~mm}$. Po analizie dostępnych środków, literatury i prób poprzednich zespołów pracujących nad tą problematyką uznano, że proces budowy urządzenia tego typu nie wymaga jedynie dostosowania, lecz kompleksowego opracowania i zweryfikowania na wszystkich jego etapach (projekt, technologia wykonania, wykonanie) [7]. W trakcie prac poświęconych konstruowaniu turbiny chłodzącej do AOS-a opracowano wiele oryginalnych i autorskich metod produkcyjnych (szerzej opisanych w innych publikacjach), sprawiających, że użycie włókna węglowego jako głównego materiału konstrukcyjnego do niewielkiego, lecz silnie obciążonego generatora strumienia chłodzącego, stało się uzasadnione [8]. Jednym z ważniejszych czynników, dzięki którym wykonanie urządzenia było możliwe, okazało się wprowadzenie do procesu produkcyjnego części kompozytowych technologii przyrostowych [9], jako metody pomocniczej znacznie ograniczającej koszty produkcyjne, alternatywnej dla części kompozytowych, służącej do wykończenia i umożliwiającej użycie rzadko stosowanych węglowych tkanin hybrydowych [10], a także jako techniki przyspieszającej proces prototypowania i weryfikacji teorii na etapie montażu zespołu chłodzącego jako całości. Brak wprowadzenia druku 3D do procesu produkcyjnego skutkowałby bardzo wyraźnym wzrostem kosztów gotowego wyrobu [11], ale przede wszystkim brakiem możliwości uzasadnionego użycia materiału kompozytowego na najistotniejsze części turbiny chłodzącej.

\section{Druk 3D jako metoda pomocnicza}

\subsection{Kształtowniki łopatek}

Druk 3D jako metoda pomocnicza miał kluczowe znaczenie w całości procesu wytwórczego gotowego zespołu chłodzącego. Zastosowanie metod przyrostowych w tym charakterze albo nie powinno być pominięte ze względów ograniczania kosztów produkcji, albo jest to wręcz jedyny możliwy sposób na wykonanie części czy narzędzi o specyficznej geometrii. Wprowadzenie druku 3D jako metody pomocniczej w procesach wyrobu elementów kompozytowych zwiększa zakres stosowalności laminatów, umożliwiając wykonywanie niewielkich części o bardzo złożonych kształtach, zapewniając wysoką jakość i powta- 
rzalność elementów. W technologii wykonania turbiny chłodzącej, przy zastosowaniu drukarki 3D, zaplanowano wytworzenie dwóch kluczowych ze względów powodzenia projektu narzędzi.

Kształtowniki łopatek wykorzystują jedną z najważniejszych zalet metod przyrostowych, jaką jest możliwość wykonywania części o geometrii, w której występują kanały o płynnie zmiennych polach przekrojów (rys. 1., rys. 2.).



Rys. 1. Kształtowniki łopatek (widok A)

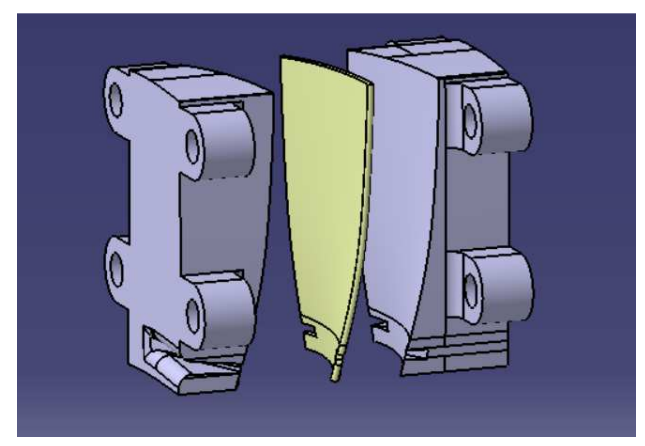

Rys. 2. Kształtowniki łopatek (widok B)

Podczas projektowania wentylatorów generujących przepływ powietrza, uznanych za najważniejsze elementy zespołu chłodzącego, napotkano na duże trudności konstrukcyjne, które rozwiązano dzięki zastosowaniu połączenia zamkowego jako metody montażowej łopatek wentylatora do tarcz. Takie rozwiązanie umożliwiło zastosowanie technologii kompozytowej do budowy wirnika, jednak wymagało opracowania sposobu otrzymywania bardzo powtarzalnej i zarazem skomplikowanej geometrii łopatek. Szybko okazało się, że łopatki o wysokości $50 \mathrm{~mm}$ wykonywane z włókna węglowego muszą być produkowane etapowo, w kilku procesach prowadzących do nadania elementom ostatecznego kształtu. Pomijając etap laminowania łopatek na formie, w którym to otrzymuje się ich surowy półfabrykat (rys. 3.), należało nadać im finalny kształt. O ile wykończenie ścianek bocznych nie stanowiłoby większych problemów technologicznych, ponieważ w procesie wytwórczym zapewniono możliwość obróbki tych sekcji jeszcze przed odformowaniem, stosując oryginalny projekt formy, to precyzyjne wykonanie nacięć umożliwiających solidny montaż gotowego wyrobu w tarczach wymagał już zaprojektowania specjalnego narzędzia. Istota działania kształtownika sprowadzała się do zamontowania łopatki wstępnie obrobionej między dwiema częściami narzędzia (rys. 4.), użycia śrub w celu uniemożliwienia ruchu półfabrykatu i wykończenia powierzchni bocznych wyrobu za pomocą obróbki ściernej (rys. 5.). Nacięcie rowków w łopatce odbywało się przy użyciu piły włosowej umieszczanej w kanałach kształtownika, które ze względu na specjalną konstrukcję wyłapywały narzędzie skrawające, ustawiając je pod odpowiednim kątem do półfabrykatu, umożliwiając powtarzalne wykonywanie operacji, co było konieczne ze względu na dużą liczbę konstrukcyjnie identycznych elementów. 


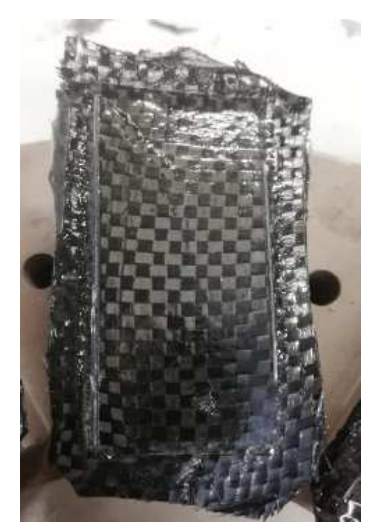

Rys. 3. Półfabrykat łopatki

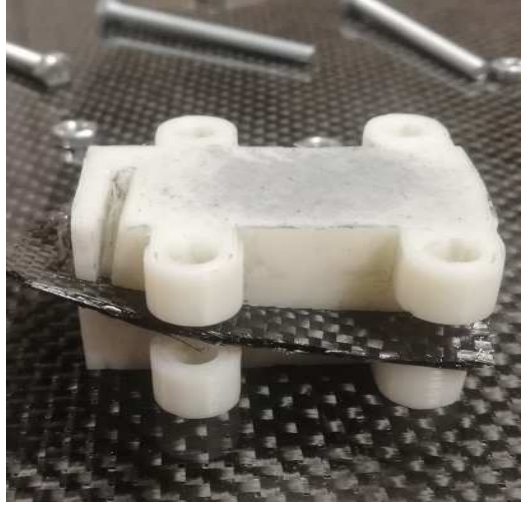

Rys. 4. Półfabrykat w kształtowniku



Rys. 5. Gotowa łopatka w kształtowniku

Kształtowniki wykonano z filamentu typu PETG, stosując stuprocentowe wypełnienie, nie przekraczając 6 godzin pracy drukarki (rys. 6.).

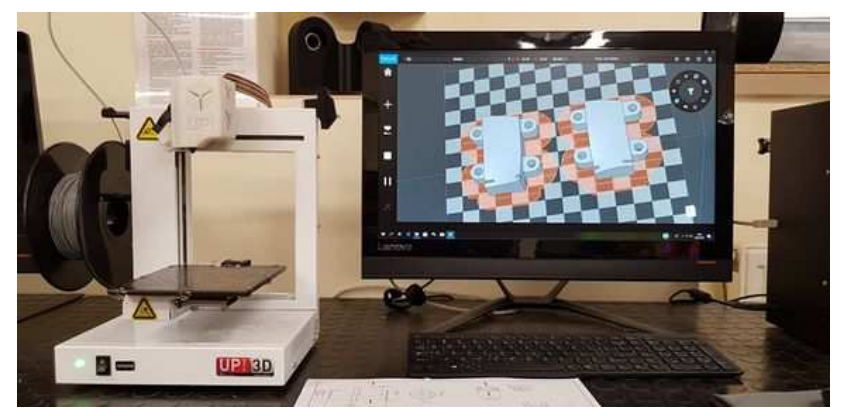

Rys. 6. Wykonanie kształtowników na drukarce 3D

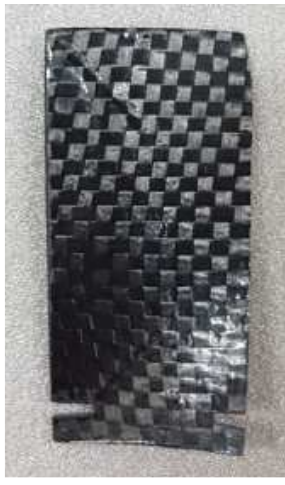

Rys. 7. Łopatka po obróbce

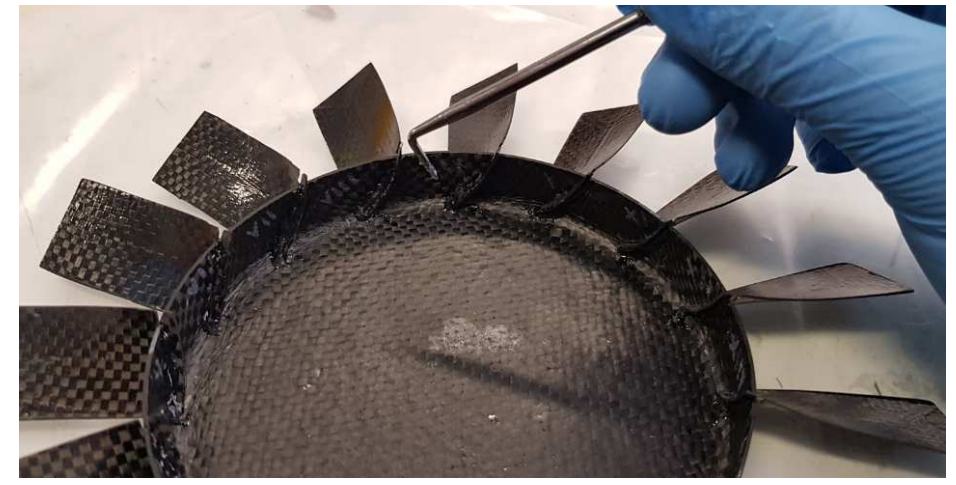

Rys. 8. Montaż łopatek do tarczy 
Tak wykonane narzędzie umożliwiało obróbkę maksymalnie 15 łopatek z zachowaniem bardzo wysokiej jakości gotowego wyrobu (rys. 7.), potwierdzoną podczas procesu montażu (rys. 8.). Ze względu na zastosowaną technologię produkcji narzędzia, ciężko jest tutaj mówić o kosztach jego wykonania, więc kształtownik z widocznymi śladami eksploatacji mógł być natychmiastowo wymieniony na nowy zestaw obróbkowy.

\subsection{Tuleja dociskowa}

Tuleja dociskowa to narzędzie, które jest doskonałym przykładem, jak w bardzo prosty sposób można znacząco ograniczyć koszty produkcji, skrócić czas wykonania i zwiększyć jakość wyrobu. Na etapie projektu elementów tarczowych wchodzących zarówno w skład wentylatora, jak i statora, okazało się konieczne, ze względów konstrukcyjnych, zastosowanie ścianek prostopadłych schodzących się pod kątem prostym lub niewielkim zaokrągleniem rzędu $\mathrm{R} 1,5 \mathrm{~mm}$, powszechnie uważanych za bardzo kłopotliwe lub niewykonalne $\mathrm{z}$ materiałów laminowanych w formach. Mając na uwadze czas wykonania form i fakt zastosowania do ich produkcji płyt akrylowych typu ProLab, których użycie powinno być ograniczane ze względów ekonomicznych, konieczne było zastosowanie technologii próżniowej, jako metody służącej do wykonania półfabrykatów większości elementów składowych. Technika ta w przeciwieństwie do metody stempla nie wymaga produkcji frezowanych docisków, które w praktyce posiadają poziom skomplikowania i wielkość głównej części formy. Worek próżniowy świetnie sprawdzał się jako docisk geometrycznie regularnych sekcji elementów tarczowych, ale jakość materiału na niewielkich promieniach przejścia (rys. 12.) czy krawędziach prostopadłych była nieakceptowalna. W celu zapewnienia wysokiej jakości wyrobu, przy zachowaniu niskich kosztów produkcji, zaprojektowano tuleję dociskową (rys. 9.), której uniwersalna konstrukcja, w zależności od sposobu montażu i ułożenia w formie, umożliwia stosowalność w produkcji wielu elementów składowych wirnika czy statora. Na przykład stosowana przy wykorzystaniu sekcji dociskowej wyposażonej w zaokrąglenie $\mathrm{R} 1,5$ służyła do produkcji tarczy przedniej wentylatora, z kolei obrócona o $180^{\circ}$ zapewniała dobrą jakość kątów prostych materiału dla obejm statora.

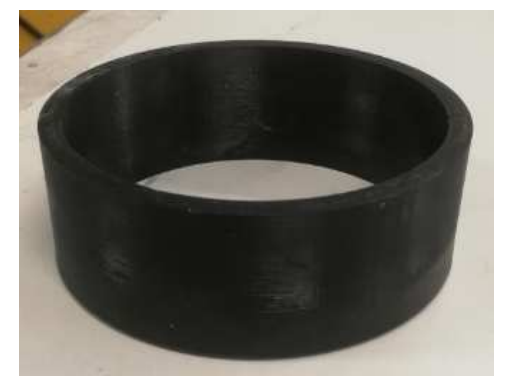


Technologia użycia tulei zakładała klasyczne ułożenie przelaminowanego materiału $\mathrm{w}$ formie i następne umieszczenie jej w worku próżniowym wraz $\mathrm{z}$ sączkami, jak w tradycyjnej metodzie niskociśnieniowej. Podczas redukcji ciśnienia należało zwrócić szczególną uwagę na pozostawienie nadmiaru worka w miejscach narażonych na niedoskonałości materiałowe tak, aby nie przyległ on do laminatu napięty. Po osiągnięciu zakładanego podciśnienia 900 mbar na elemencie umieszczano tuleję dociskową (rys. 10.) nałożoną odpowiednią stroną w kierunku laminatu i następnie obciążano dwukilogramowym ciężarkiem (rys. 11.).

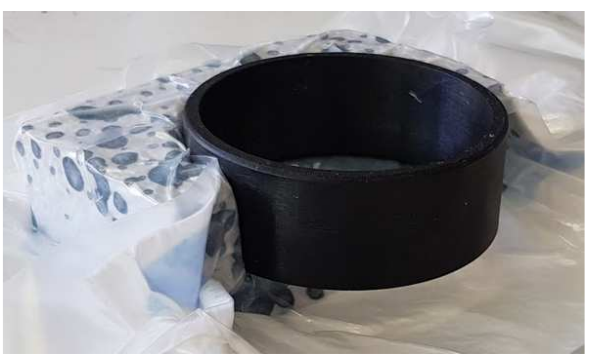

Rys. 10. Tuleja dociskowa jako stempel

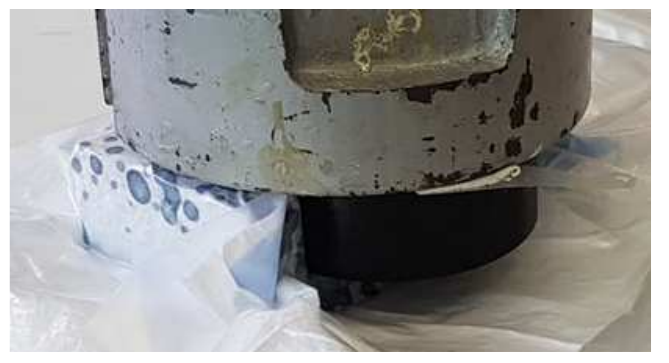

Rys. 11. Obciążenie tulei zapewniające odpowiedni docisk przelaminowanego materiału

Tak zaprojektowany proces produkcyjny świadczy o zastosowaniu technologii hybrydowej łączącej ze sobą techniki próżniowe i metodę stempla, zapewniając wysoką jakość wyrobu. Poprawa struktury laminatu, przy zastosowaniu nowej i specjalnej technologii produkcyjnej, jest widoczna gołym okiem na warstwach zewnętrznych (rys. 13.), ale wpływa także znacząco na jakość materiału $\mathrm{w}$ przekroju gotowego elementu, nawet $\mathrm{w}$ miejscach krytycznych, takich jak promienie przejścia (rys. 14.), szczególnie istotną w urządzeniach wysokoobrotowych.

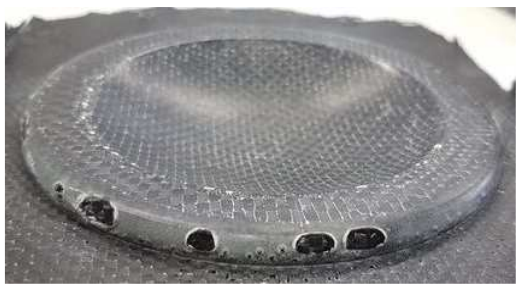

Rys. 12. Widoczne nieciągłości materiału przy zbyt słabym docisku na krawędzi tarczy

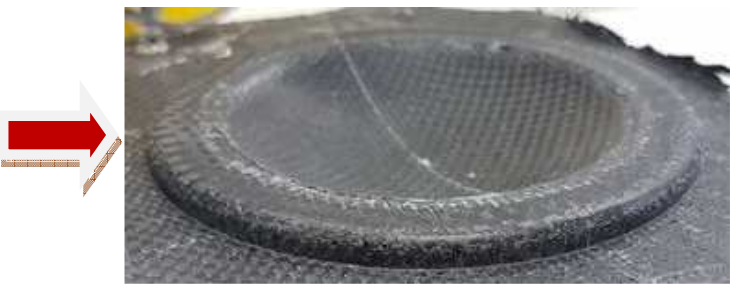

Rys. 13. Poprawnie wykonana tarcza

Do wykonania tulei dociskowej posłużyła standardowa drukarka laboratoryjna zasilana filamentem typu PETG. Poziom wypełnienia druku powinien być dobrany odpowiednio do siły, z jaką tuleja będzie dociskana do laminatu, 
Rys. 14. Prawidłowo wykonany promień przejścia

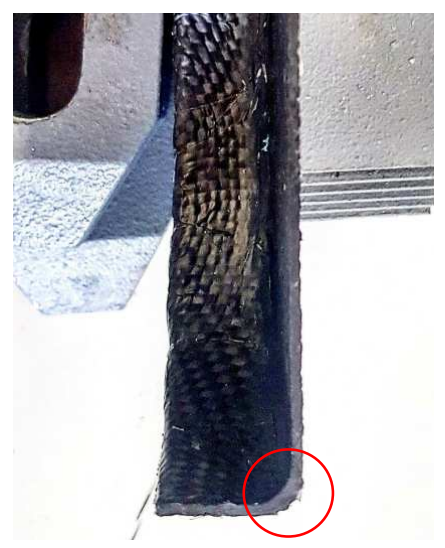

ponieważ jej sztywność ma kluczowe znaczenie dla finalnego kształtu wyrobu. Tuleja stosowana do produkcji turbiny chłodzącej była drukowana przy $90 \%$ wypełnieniu i nie wykazywała żadnych oznak odkształceń przy obciążeniu do $6 \mathrm{~kg}$. Brak opracowania technologii hybrydowej z zastosowaniem technik przyrostowych skutkowałby koniecznością produkcji co najmniej pięciu stempli, które w celu poprawności swojego działania w praktyce pochłonęłyby ilość materiału typu ProLab równoważną tej, zastosowanej na główne części formy, zwiększając tym samym o nawet $60 \%$ liczbę koniecznych do wyfrezowania wzorników, co w bardzo znaczący sposób wpłynęłoby na wzrost kosztów projektu i jego czas realizacji.

\section{Druk 3D jako metoda zamienna}

Stator to część konstrukcji łącząca rdzeń zespołu chłodzącego z korpusem, stanowiąc pewnego rodzaju szkielet całego złożenia, dlatego też jego budowa i podział musiały zostać starannie zaprojektowane w celu nadania mu odpowiedniej wytrzymałości z możliwością zapewnienia chłodzenia dla silników (poniekąd schowanych wewnątrz statora) - rys. 15. - napędzających wentylatory obrotowe. Projekt zakładał, aby obydwa podzespoły (wentylator z silnikiem) zostały przymocowane do statora za pomocą specjalnie zaprojektowanego stojanu silni$\mathrm{ka}$, natomiast już sam stator zapewnił połączenie z korpusem poprzez gwintowane pręty metalowe (rys. 16.) działające na zasadzie napinacza.

W przypadku takiego rozwiązania łopatki statora pełnią rolę jedynie aerodynamiczną i nie są narażone na działanie dużych obciążeń, dlatego też możliwe było ich wykonanie w sposób zapewniający jak najmniejszą masę. Wykorzystując fakt, że mają one jedynie funkcję owiewki dla prętów, zdecydowano, że będzie możliwe przeprowadzenie przez ich wnętrze kanałów chłodzących, doprowadzających i odprowadzających powietrze z silników. 


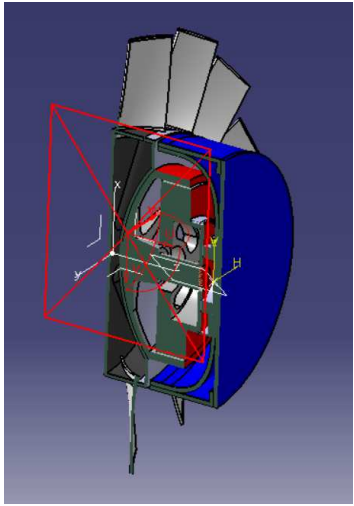

Rys. 15. Montaż silnika wewewnątrz statora i wentylatora

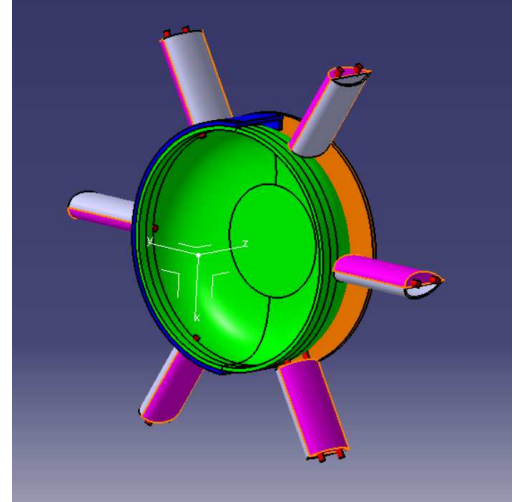

Rys. 16. Koncepcja złożenia statora

Koncepcja początkowa zakładała wykonanie łopatek w technologii kompozytowej przy użyciu niezwykle lekkiego materiału węglowego, carbowave $20 \mathrm{~g} / \mathrm{m}^{2}$. Dwie symetryczne formy wykonano z materiału typu ProLab, umieszczając $w$ jednej $\mathrm{z}$ nich rowki przeznaczone na gwintowane pręty łączące stator $\mathrm{z}$ korpusem. Laminowanie odbywało się w technologii sandwitchowej z przekładką z rochacelu $1 \mathrm{~mm}$, a następnie po utwardzeniu żywicy i wstępnej obróbce sklejono gotowe powierzchnie (rys. 17.).

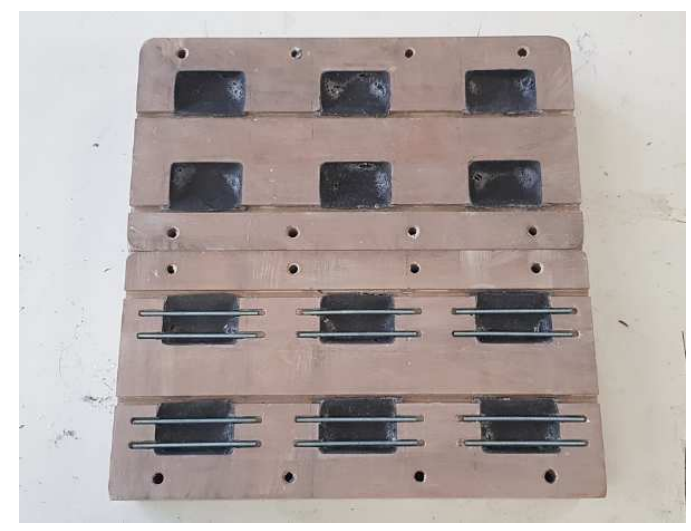

Rys. 17. Proces produkcji węglowych łopatek statora

Okazało się, że próba laminowania tak małych elementów w technologii sandwitchowej z użyciem próżni nie jest, w tym wypadku, najlepszą metodą, gdyż materiał został zbyt słabo dociśnięty i pojawiły się na nim nieciągłości. Dodatkowo, niedokładnie wykonane formy spowodowały brak zachowania profilu w gotowym produkcie, przez co utracił on właściwości aerodynamiczne. 
$\mathrm{Z}$ powodu nieudanej próby wylaminowania elementu oraz zmniejszającej się ilości czasu na finalizację projektu, podjęto decyzję o rezygnacji z budowy łopatek z użyciem materiału węglowego, ze względu na długi czas oczekiwania na frezowanie nowych form i skomplikowany proces technologiczny, zastępując je pylonami wykonanymi w technologii przyrostowej.

Łopatki drukowano w dwóch podejściach. Na początku przeprowadzono eksperyment sprawdzający, czy elementy wykonane z podatnego filamentu TPU (rys. 18.), który po połączeniu wszystkich elementów miał dopasować się do korpusu oraz statora i zapewnić redukcję drgań przenoszonych z rdzenia turbiny na jej korpus, mogą zagwarantować pożądaną sztywność złożenia. Biorąc pod uwagę ścisk materiału, wykonano je z naddatkiem $2 \mathrm{~mm}$. Test w warunkach $30 \%$ nominalnych obrotów silnika wykazał, że filament ten jest zbyt miękki, co spowodowało zupełną kompensację luzu wierzchołkowego łopatek wentylatora (rys. 19., rys. 20.), koniecznego do utrzymania ze względów bezpieczeństwa, prowadząc przy większych obrotach do ich zderzenia z korpusem.

Rys. 18. Drukowanie łopatki z filamentu TPU

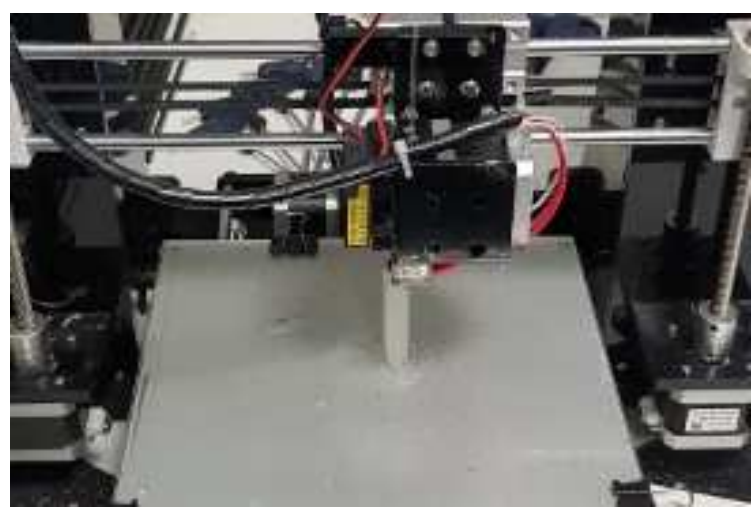

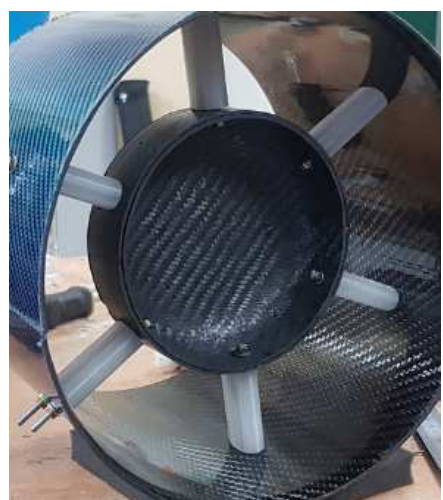

Rys. 19. Próbny montaż



Rys. 20. Montaż z wentylatorem (test luzu wierzchołkowego) 
Po porównaniu profili łopatek wykonanych z włókna węglowego i techniką przyrostową (rys. 21., rys. 22.), które dowiodło dużo większą dokładność tej drugiej metody w wypadku elementów w tak niewielkiej skali, zdecydowano się podjąć drugą próbę druku, tym razem z zachowującego dużo większą sztywność filamentu PETG.

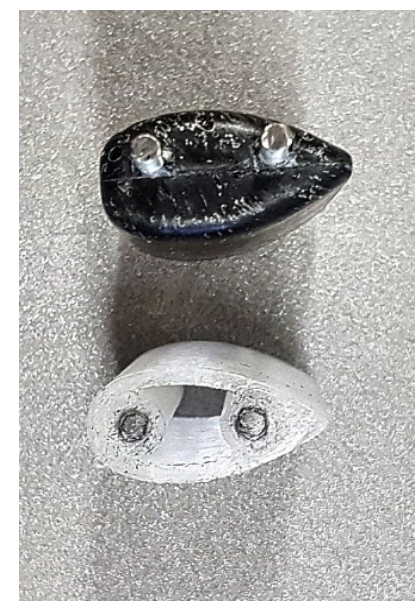

Rys. 21. Porównanie dokładności odwzorowania profilu

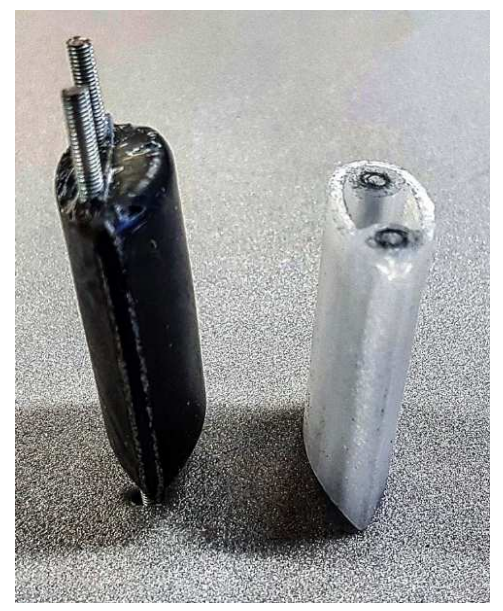

Rys. 22. Porównanie spływu łopatek

Drugi wydrukowany z filamentu PETG (rys. 23.), komplet łopatek statora spełnił wszystkie założenia projektowe. Pylony zachowały pożądany kształt, zapewniły luz wierzchołkowy łopatkom wentylatora, a zaplanowane otwory pod pręty umożliwiły solidne i sztywne połączenie (rys. 24., rys. 25.). Zastosowanie technologii przyrostowej zapewniło dokładne wykonanie nie tylko profilu łopatek, ale również skomplikowanego geometrycznie przekroju zaprojektowanego tak, aby umożliwić przeprowadzenie przez stator chłodzenia silników.

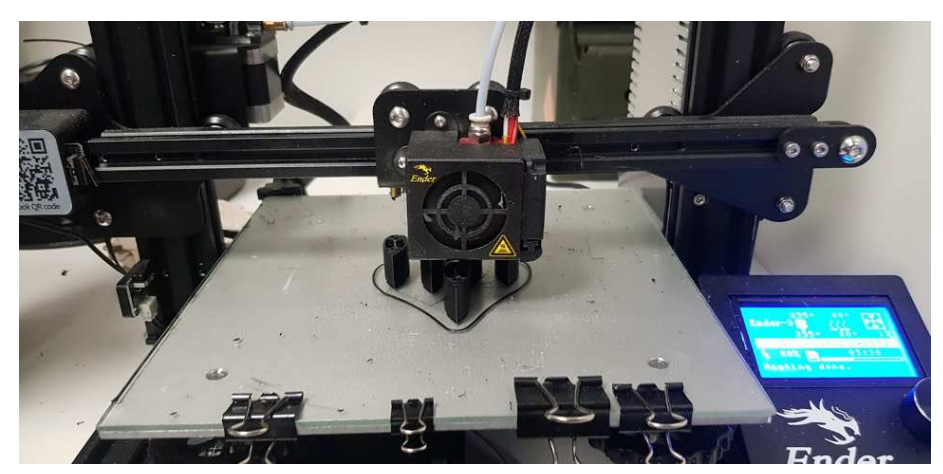

Rys. 23. Druk łopatek z filamentu PETG 


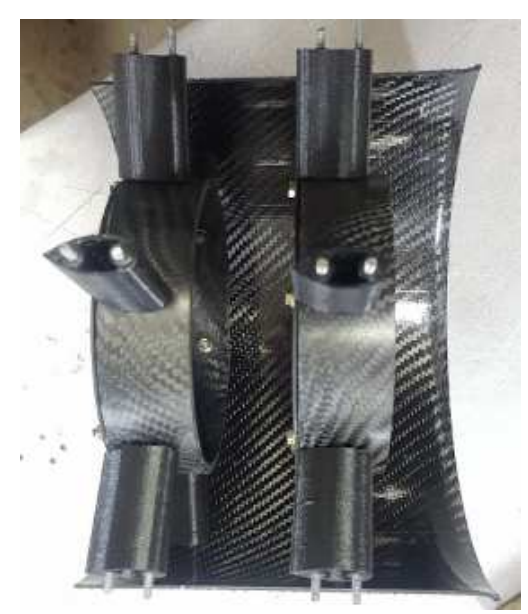

Rys. 24. Próbny montaż (A)

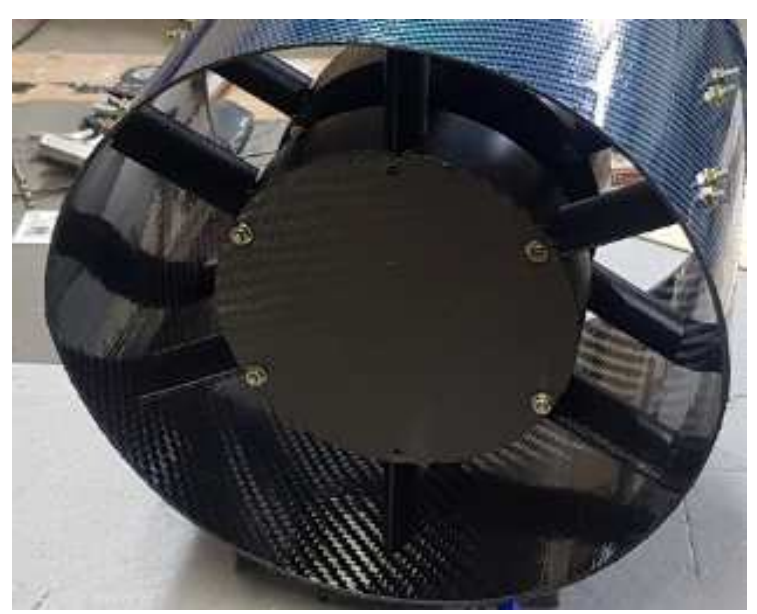

Rys. 25. Próbny montaż (B)

Porównując obydwie techniki (rys. 26., rys. 27.), stwierdzono, że metoda druku 3D okazała się być znacznie szybsza (komplet 6 łopatek drukował się 9 godzin, natomiast sam czas na utwardzenie żywicy w przypadku łopatek laminowanych wyniósł 12 godzin). Dodatkowo należy zwrócić uwagę na nieporównywalnie mniejsze koszty produkcji łopatek z filamentu PETG, jednak kluczowa w wyborze ostatecznej techniki wytworzenia była dokładność wykonania. Druk 3D zapewnił pożądane odwzorowanie kształtu profilu, a także umożliwił wykonanie bardziej wydajnych kanałów chłodzących silniki.

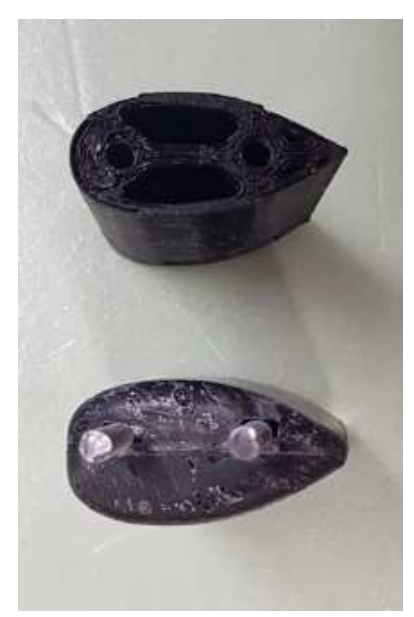

Rys. 26. Porównanie profili łopatek

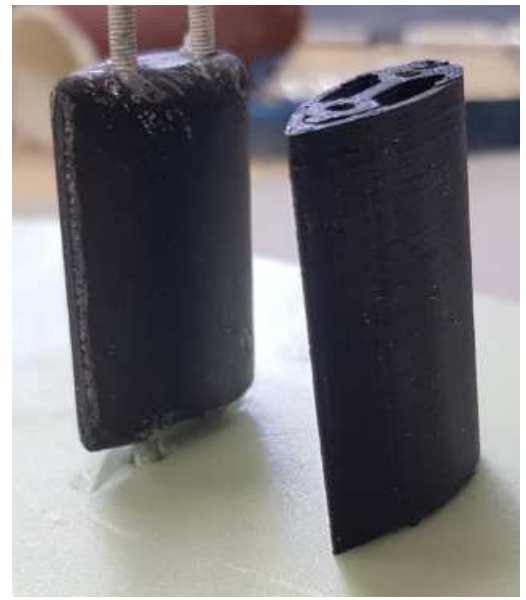

Rys. 27. Porównanie spływów łopatek 


\section{Druk 3D jako metoda wykończeniowa}

Do budowy korpusu zespołu chłodzącego zastosowano hybrydową tkaninę węglową przeplataną włóknem kevlarowym. Taki typ materiału odznacza się wysoką odpornością na uszkodzenia mechaniczne (w tym wypadku ewentualną dezintegrację elementów rdzenia turbiny w przypadku awarii), jednak podczas obróbki półfabrykatu przy użyciu papieru ściernego wykazuje niezachowanie integralności włókien kevlaru z osnową żywicy. Dlatego też chcąc wykorzystać jego właściwości wytrzymałościowe należało opracować metodę zapobiegającą niszczeniu tkaniny, lecz równocześnie umożliwiającą konieczną obróbkę krawędzi obudowy. Analizując dostępne zaplecze technologiczne zdecydowano się na zastosowanie druku 3D (rys. 28.) do wytworzenia elementów ochronnych w postaci uszczelek zabezpieczających, wykonanych $\mathrm{z}$ podatnego filamentu TPU (rys. 29.).

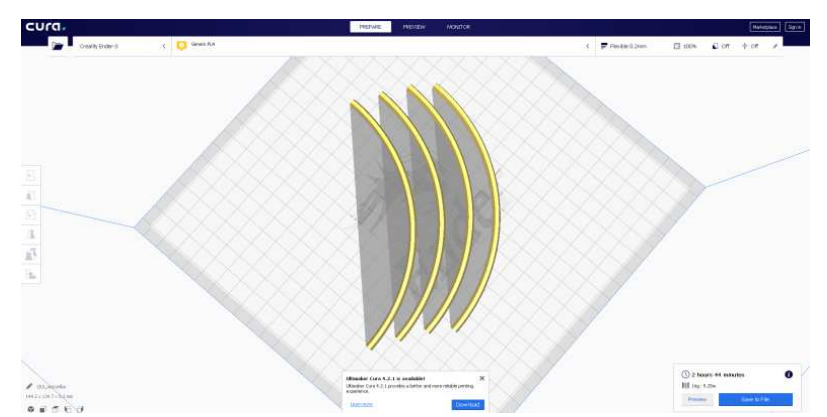

Rys. 28. Modele uszczelek na stole drukarki w programie Cura

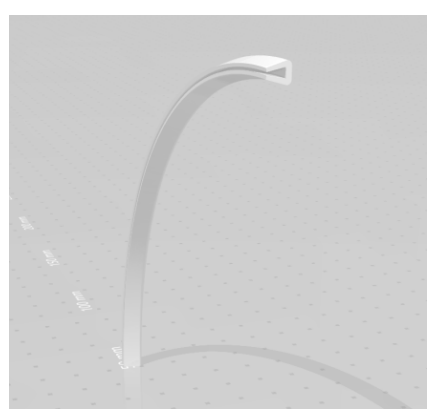

Rys. 29. Model uszczelki zabezpieczającej

Na podstawie modelu korpusu, uszczelki zaprojektowano tak, aby ich kształt dokładnie dopasował się do krawędzi obudowy (rys. 30.). Taki typ zabezpieczenia pełni rolę ochronną przed strzępieniem kompozytu oraz daje możliwość szczelnego montażu (rys. 31.) z wylotem kanału chłodzącego ogniwo paliwowe motoszybowca. Dodatkowo element ten jest niezwykle przydatny w czasie montażu całego zespołu, który przez swój cylindryczny kształt utrudnia pracę przy złożeniu. Uszczelki, pełniąc rolę zabezpieczającą, umożliwiają postawienie turbiny na krawędzi korpusu przy zdemontowanym stożku wylotowym. Mając na uwadze zalety użytkowania tego typu elementów ochronnych, należy pamiętać, że wynikają one niemal wyłącznie z wykorzystania technologii przyrostowych do ich produkcji. W przypadku próby wykonania tych części innymi metodami tradycyjnymi koszty materiału i wyrobu byłyby nieadekwatne co do stosowalności elementu. Koszty produkcji uszczelek z filamentu TPU można uznać za cząstkowe względem całości projektu, a pozwalają one na użycie tkanin kevlarowo-węglowych bez obaw związanych z ich naturalnymi skłonnościami do strzępienia. Dodatkowo TPU wykazuje dobre właściwości uszczelniające ze 
względu na swoją podatność i strukturę podobną do twardego sylikonu, dzięki czemu jednostkowa i niskoseryjna produkcja staje się opłacalna i uzasadniona.

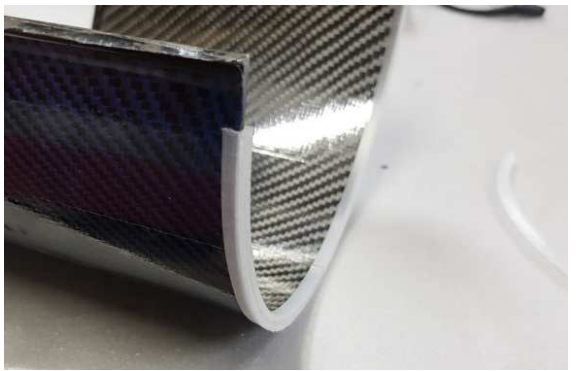

Rys. 30. Dopasowanie uszczelki do krawędzi korpusu



Rys. 31. Uszczelka na złożonej turbinie

Wytwarzanie za pomocą technologii przyrostowych znalazło swoje zastosowanie również $w$ przypadku innych elementów wykończeniowych, takich jak wloty powietrza do kanałów chłodzących. Są to elementy poprawiające wydajność chłodzenia poprzez zwiększenie masowego natężenia przepływu powietrza w otworach zaprojektowanych w łopatkach statora i korpusie. Zostały one wykonane $\mathrm{z}$ podatnego filamentu TPU (rys. 32.). Zdecydowano się na zastosowanie tego typu materiału, ze względu na to, że wloty wystają poza obrys korpusu (rys. 33.), przez co są narażone na wszelkiego rodzaju uszkodzenia, chociażby podczas montażu zespołu. Miękki filament nie wykazuje skłonności do łamania czy kruszenia się, a jego struktura podatna na punktowe nadtapianie podczas utwardzania żywicy, ze względu na jej wysoką temperaturę żelowania, sprawia, że połączenie z korpusem, w specjalnie zaprojektowanych, nacinanych rowkach, jest trwałe ze strukturą kompozytu. Zastosowanie druku 3D miało tutaj kluczowe znaczenie, ponieważ skomplikowana geometria wlotów wykluczała inne możliwości wytwórcze tych elementów.

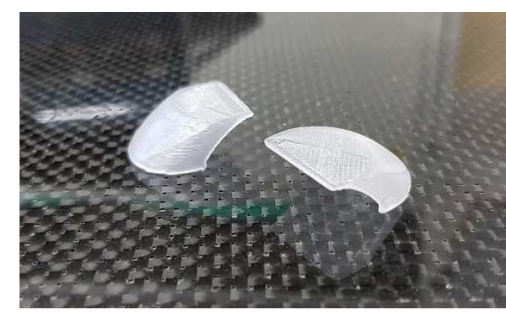

Rys. 32. Wloty powietrza

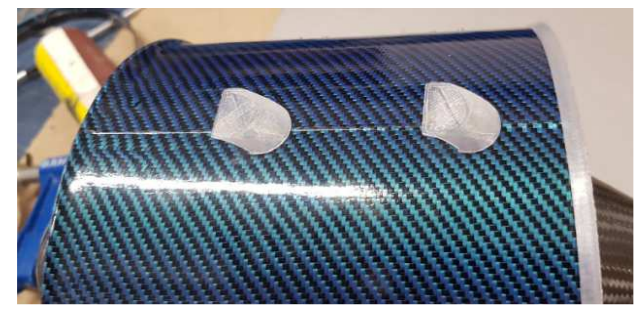

Rys. 33. Próbny montaż wlotów na korpusie

Zastosowanie technik przyrostowych uznano za najlepszą metodę produkcji jednostkowej czy małoseryjnej części wykończeniowych. Elementy te przyczyniły się znacząco do poprawy jakości całego zespołu chłodzącego, zarówno 
w kwestii jego sprawności (wloty doprowadzające powietrze chłodzące do silników) i jako części zabezpieczające (uszczelki z podatnego filamentu), zwiększające estetykę i ułatwiające eksploatację turbiny.

\section{Druk 3D w budowie modeli pomocniczych}

Jedną z ram projektowych narzuconą z góry na konstruktorów turbiny chłodzącej była konieczność użycia silników Hacker Q80-13XS. Pomijając fakt dużych wymiarów średnicowych napędu, znacznie wpływających na problematykę budowy wentylatora poprzez konieczność użycia jedynie $50 \mathrm{~mm}$ łopatek, konstrukcja silników musiała zostać dostosowana. Przeprojektowaniu należało poddać łoże silnika oraz zastosować zmiany w kształcie jego stojanu. Ze względu na duży koszt pary silników do dwustopniowej turbiny i ewentualne ryzyko uszkodzeń części laminatowych zdecydowano się na weryfikację teorii zmian konstrukcyjnych $\mathrm{w}$ praktyce poprzez zamodelowanie napędu $\mathrm{w}$ programie Catia (rys. 34., rys. 35.) wraz ze wszystkimi poprawkami i nowym, zaprojektowanym specjalnie na potrzeby konstrukcji statora, łożem (rys. 36., rys. 37.) w celu wytworzenia za pomocą metod przyrostowych ich prototypów. Rzeczywiste modele (rys. 38.) pozwoliły także na przeprowadzenie próbnego montażu na wyprodukowanych już elementach zespołu chłodzącego (rys. 39.-41.), znacznie ułatwiając końcowe prace wykończeniowe. Sam fakt wykorzystania druku 3D jako

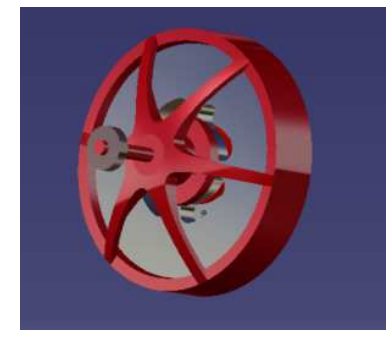

Rys. 34. Model napędu (widok A)



Rys. 36. Model łoża silnika (widok A)



Rys. 35. Model napędu (widok B)

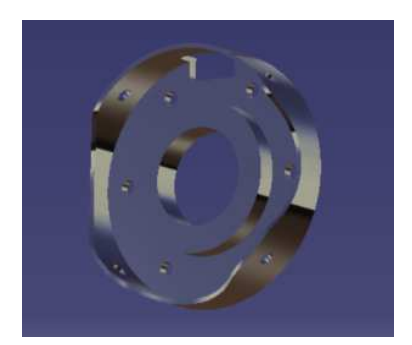

Rys. 37. Model łoża silnika (widok B) 
Rys. 38. Wydrukowane części modeli silników

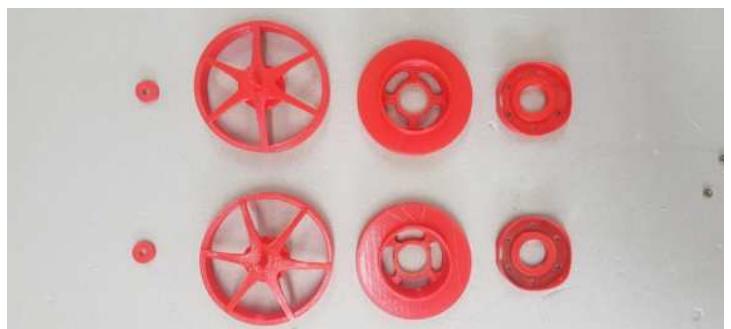

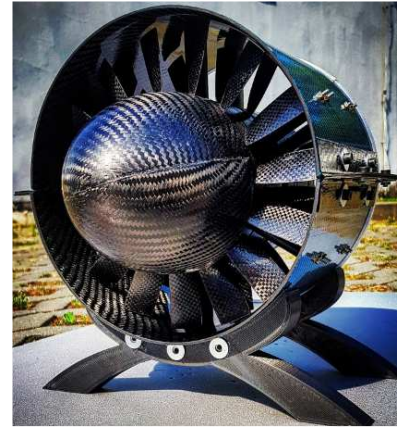

Rys. 39. Złożony, z zastosowaniem modelu silnika, zespół chłodzący (widok A)

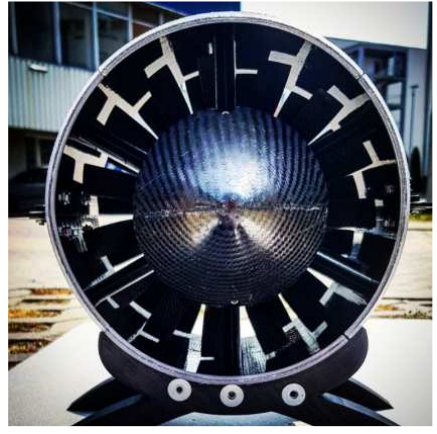

Rys. 40. Złożony, z zastosowaniem modelu silnika, zespół chłodzący (widok B)

Rys. 41. Rdzeń zespołu chłodzącego złożony z zastosowaniem modeli silników

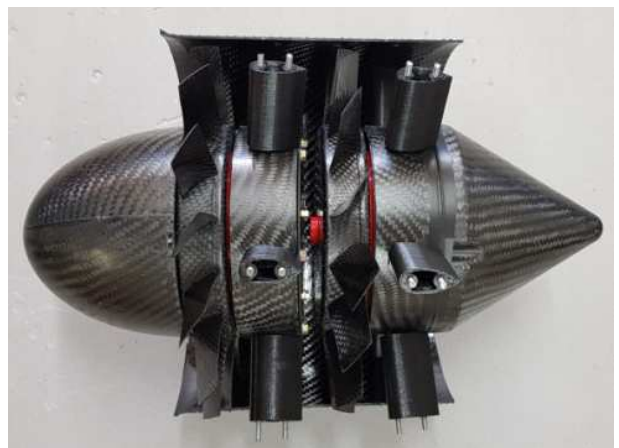

metody szybkiego prototypowania jest stosunkowo powszechny, jednak należy zwrócić uwagę na zalety stosowania prototypów podzespołów współpracujących z drogimi w produkcji elementami kompozytowymi, aby nie dopuszczać do ich ewentualnych uszkodzeń.

\section{Podsumowanie i wnioski}

Prace nad turbiną chłodzącą do AOS-a pokazały, jak istotnym czynnikiem w procesie projektowania i budowy jest otwartość na nowe technologie, stoso- 
wanie nieschematycznych i oryginalnych rozwiązań, sprawiających, że jest możliwe wzniesienie współczesnej inżynierii na nowy poziom. Przyszłością maszyn latających są materiały kompozytowe, ponieważ zalety płynące $\mathrm{z}$ ich stosowania powodują zwiększenie sprawności czy ekonomiczności lotu. Obecne projekty części i technologie wykonania podzespołów samolotu powinny wykraczać poza standardowe utarte szlaki, aby w sposób uzasadniony zwiększyć skład procentowy laminatów w konstrukcji nie tylko płatowca, ale także reszty jego wyposażenia. Prace nad turbiną chłodzącą dowiodły, że pomimo powszechnej opinii, co do konstrukcji wentylatora mówiącej o niepowodzeniu projektu w takiej formie przy zastosowaniu materiałów kompozytowych, możliwe jest opracowanie technologii wykonania w taki sposób, aby sprostała ona wymaganiom sytuacji. Druk 3D w klasycznej formie (standardowe drukarki i filamenty) nie może być uznawany za dobrą metodę wykonywania odpowiedzialnych podzespołów, ale jako technologia pomocnicza $\mathrm{w}$ produkcji części kompozytowych zwiększa stosowalność laminatów, likwidując znaczące ograniczenia, takie jak wielkość i złożoność geometryczna pojedynczych części czy problemy z dociskiem przesączonej tkaniny na zaokrągleniach, przy jednoczesnej, znaczącej redukcji kosztów wykonania.

\section{Literatura}

1. Sklorz R., Puzio Ł., Brodny J., Wstępna analiza wpływu wybranych czynników zewnętrznych i parametrów eksploatacyjnych transportowego samolotu odrzutowego na zużycie paliwa, Systemy wspomagania w Inżynierii Produkcji, 2017.

2. Balicki W. i in., Lotnicze silniki turbinowe, konstrukcja - eksploatacja - diagnostyka, część 1, Biblioteka naukowa Instytutu Lotnictwa, Warszawa 2010.

3. Bielawski R., Rozprawa doktorska: Badanie i modelowanie połączeń nitowych w lotniczych strukturach kompozytowych, Politechnika Warszawska, Warszawa 2016.

4. Merkisz J., Bajerlein M., Materiały kompozytowe stosowane we współczesnych statkach powietrznych, Czasopismo Logistyka, 2013.

5. Bieniaś J., Struktura i właściwości materiałów kompozytowych, Politechnika Lubelska, Lublin 2002.

6. Kaczorowska K., Jakubowski M., Praca dyplomowa: Projekt i wykonanie kompozytowego wentylatora chłodzącego ogniwo paliwowe motoszybowca AOS-H2, Politechnika Rzeszowska, Rzeszów 2019.

7. Szymański R., Technologia wykonania noska łopaty wirnika nośnego, porównanie trzech technologii, Instytut lotnictwa, Warszawa 2016.

8. Kaczorowska K., Jakubowski M., Praca dyplomowa: Projekt i wykonanie kompozytowego wentylatora chłodzącego ogniwo paliwowe motoszybowca AOS-H2, Politechnika Rzeszowska, Rzeszów 2019.

9. Wytwarzanie przyrostowe, Wydawnictwo Trade Media International, 2019, https://www.designnews.pl/menu-gorne/artykul/article/wytwarzanie-przyrostowe/ ?fbclid=IwAR3rHpvsQeJ1NVrQ-qgKRbjI2CVGayDxwurqmOLln5bUkHQ16IfYVv HamSQ (dostęp: 03.09.2020). 
10. Fejdyś M., Łandwijt M., Włókna techniczne wzmacniające materiały kompozytowe, Techniczne Wyroby Włókiennicze, 2010.

11. Jak czterokrotnie obniżyć koszty produkcji jednostkowego modelu?, ATMAT, 2020, https://atmat.pl/cnc-vs-druk-3d (dostęp: 03.09.2020). 
